\title{
Behavioural Responses in Pigs administered with Ascorbic acid and Transported by Road for Eight Hours during the Harmattan Season
}

\author{
Yahaya Adeshina Adenkola \\ University of Agriculture, Makurdi, Nigeria \\ * Corresponding author email: aadenkola@yahoo.com \\ Received: 05-03-2011, Accepted: 08-04-2011, Published Online: 04-06-2011
}

\begin{abstract}
Experiments were carried out with the aim of investigating the modulatory role of ascorbic acid (AA) on responses to 8$\mathrm{h}$ road transportation, covering a distance of $260 \mathrm{~km}$ at a speed of $40-50 \mathrm{~km} / \mathrm{h}$, during the harmattan season. Twentynine adult local pigs aged 9 - 12 months served as subjects. Seventeen pigs administered with AA, prior to the transportation, at the dose of $250 \mathrm{mg} / \mathrm{kg}$ orally and individually served as experimental animals, and 12 others administered orally with sterile water were used as control animals. The behavioural activities of pigs which included resting (that is, either lying down or standing idle), defaecating, urinating, sniffing, threats of attack (fight), attempts to escape, mounting on one another, hurdling together and routing the floor were monitored with the aid of a video camera without the pigs knowing that they were being observed. Recordings were done based on the number of pigs found performing each activity within $30 \mathrm{~min}$ of direct observation, alternated by $30 \mathrm{~min}$ of rest and this continued for a period of $4 \mathrm{~h}$. The tape was later watched, analysed and the number of pigs exhibiting each behavioural activity was recorded. Post-transportation, the behavioural activities of standing $(94.1 \pm 5.8 \%)$, aggressiveness indicated by the percentage of pigs involved in fighting $(23.5 \pm 6.00 \%)$ and attempts to escape $(66.67 \pm 14.21 \%)$ were higher in experimental pigs (P $<0.05)$ post-transportation than control pigs with the corresponding values of $25.00 \pm 3.00 \% ; 0.00 \%$ and $35.29 \pm 11.95$ $\%$, respectively. The results showed that road transportation induced considerable behavioural stress resulting in depression of the central nervous system. AA administration pre-transportation reduced the manifestation of stressful behavioural activities in experimental pigs following road transportation. In conclusion, long-term road transportation of pigs during the harmattan season induces behavioural stress, alleviated by AA administration.
\end{abstract}

Key words: Ascorbic acid, Behavioural responses, Harmattan season, Pigs, Road transportation.

\section{I ntroduction}

Road transportation is a critical phase in animal production and utilization. The current UK legislation [Welfare of Animals (Transport) Order, 1997] states that pigs can be transported for a maximum of eight hours after which they must be unloaded, fed, watered and rested for 24 hours before any further journey (Brown et al., 1999). This standard is currently undergoing a review for improved welfare order (Gavinelli and Simonrin, 2003). Long-term transportation of livestock by road across various ecological and climatic zones imposes many stressors upon the animals which overtax the body system (Hartung, 2003) and is often considered as one of the main causes of stress (Earley et al., 2006; Buchham Sporer, et al., 2008; Adenkola et al., 2010), and it adversely affects production both in economic and animal welfare terms (Broom, 2003). Behavioural changes are often the first signs of distress (Ayo et al., 2002), and animal welfare may be assessed based on them (Hicks et al., 1998).

Ascorbic acid (AA) or Vitamin C is a naturally occurring antioxidant (Sahin et al., 2001) found to be beneficial in ameliorating stressful situation and currently is the most widely used vitamin supplement throughout the world (Naidu, 2003). AA is an effective antioxidant because it plays an important metabolic role in the body by acting as a potent scavenger of free radicals by donating two electrons and then becoming oxidized to dehydro-L-ascorbic acid (Rice, 2000). Free radicals causing oxidative stress in the brain have been shown to be involved in stress-induced neurobehavioural changes (Pal et al., 2006), excitotoxicity (Ray et al., 2007) and AA has been shown to have neuroprotective abilities (Santiago-Mejia, 2004).

The harmattan season in Nigeria is a cold-dry season occurring between the month of November and February in the Northern Guinea Savannah zone (Igono et al., 1982). It is characterized by high ambient 
temperature (AT) in the afternoon hours of the day, and relatively low AT late in the evening and early hours of the day (Ayo et al., 1998). The wind during the season is cold-dry and dust laden (Igono and Aliu, 1982). The changes in thermal environment caused by fluctuations in AT and relative humidity $(\mathrm{RH})$ have been demonstrated to induce a variety of physiological responses, which may adversely affect productivity and health in livestock (Ayo et al., 1998). In Nigeria the season coincides with Christmas and New Year celebrations, during which livestock are transported in large number from the northern to the southern part of the country and across various ecological and climatic zones for the celebrations. Many farmers in the zone practise mixed farming and they sell pigs to generate cash in order to buy items needed for the end-of-the year celebrations (Ayo et al., 2006).

Currently, there is paucity of information on behavioural stress responses of pigs transported by road during the harmattan season.

The aims of the study, therefore, were to investigate the effect of long-term (8-h) road transportation on behavioural stress responses of pigs during the harmattan season and the modulatory role of AA administration on the responses.

\section{Materials and methods}

Experimental Site: The experiments were performed during the harmattan season, at the Livestock Research Pen, Faculty of Veterinary Medicine, Ahmadu Bello University, Samaru-Zaria $\left(11^{0} 10^{\prime} \mathrm{N}, 07^{0} 38^{\prime} \mathrm{E}\right)$, located in the Northern Guinea Savannah zone of Nigeria.

Experimental Animals and Management: Twenty nine local pigs, including males and non-pregnant, non-nursing females, weighing $20-48 \mathrm{~kg}$, and with ages ranging from $9-12$ months were bought from different localities in Zaria environs two weeks before the experimental day. They were kept under an intensive system of management. The pigs were preconditioned for two weeks before the commencement of the experiment. During the period, they were preconditioned to experimental procedure and screened for diseases by taking their blood and faecal samples for laboratory analyses. The infested pigs were treated using oxytetracycline at the dose of $20 \mathrm{mg} / \mathrm{kg}$ and thiabendazole (M.S.D. AGVET, U.S.A.) at the dose of $25 \mathrm{mg} / \mathrm{kg}$ body weight.

Experimental Design: On the experimental day, the experimental pigs $(n=17)$ were orally and individually administered with AA (Juhel Nigeria Ltd., Enugu, Nigeria.) at $250 \mathrm{mg} / \mathrm{kg}$ (Chervyyakov et al., 1977) dissolved in $20 \mathrm{ml}$ of water, while 12 pigs which served as control were similarly given $20 \mathrm{ml}$ of sterile water. Food and water were withdrawn 12 hours before and throughout the journey period, which lasted 8 hours. Two persons loaded the pigs into the vehicle under relatively calm conditions. One person caught and carried a pig and led it to the other person, already inside the vehicle, who in turn placed the pig into the vehicle. The pigs were stocked at the density of $0.8 \mathrm{~m}^{2}$ per animal. The journey commenced at 8:00 h. Other transportation procedures were carried out in accordance with the standard guidelines governing the welfare of pigs during road transportation (Lambooij, 2000).

The vehicle travelled from Zaria $\left(11^{0} 10^{\prime} \mathrm{N}, 07^{0}\right.$ $\left.38^{\prime} \mathrm{E}\right)$ to Pambegua $\left(10^{\circ} 4^{\prime} \mathrm{N}, 08^{0} 16^{\prime} \mathrm{E}\right)$ along Zaria-Jos road and back to Zaria on tarred road. The vehicle covered $260 \mathrm{~km}$ at a speed range of $40-50 \mathrm{~km} / \mathrm{h}$. After completing the journey, the pigs were unloaded at the spot where they were original loaded. The animals were fed and watered as they had been prior to the journey.

Determination of behavioural activities: The behavioural activities of pigs which included standing, lying down, sniffing, mounting, fight, routing the floor, huddling together, eating, drinking, attempt to escape, defaecation and urination were observed as described by Knowles et al. (1999). Recordings were done based on the number of pigs found performing each activity within $30 \mathrm{~min}$ of direct observation, alternated by $30 \mathrm{~min}$ of rest and this continued for a period of $4 \mathrm{~h}$. The video tape was later watched and the number of pigs exhibiting each behavioural activity was recorded.

Statistical Analysis: Behavioural activities for each period of measurement were summed and results presented as percentiles. Data subjected to Student's $t$ test and are expressed as mean \pm standard error of the mean (mean $\pm \mathrm{SEM}$ ). Values of $\mathrm{P}<0.05$ were considered significant.

\section{Results}

Meteorological Data: The meteorological data from the study period pre-transportation are shown in Table-1. The period was characterized by relatively low minimum AT of $19.0 \pm 3.1^{\circ} \mathrm{C}$ and low maximum AT of $23.3 \pm 0.7^{\circ} \mathrm{C}$. The DBT value obtained during the recordings was $19.2 \pm 2.7^{\circ} \mathrm{C}$. The harmattan season was characterized by relatively low humidity of $21.0 \pm$ $0.51 \%$ pre-transportation and $21.0 \pm 0.6 \%$ posttransportation. The wind direction was North-east with a speed of $226.43 \mathrm{~km} /$ day. The meteorological data during the post-transportation period (Table 2) 
Behavioural Responses in Pigs administered with Ascorbic acid and Transported by Road for Eight Hours

Table-1. Meteorological Data for the Study Period Pre-Transportation

\begin{tabular}{lccccc}
\hline Hour & \multicolumn{2}{c}{ Ambient Temperature $\left({ }^{\circ} \mathbf{C}\right)$} & Relative Humidity (\%) & Wind speed (km/ day) \\
\cline { 2 - 4 } & Minimum & Maximum & Dry-bulb & & \\
\hline 06: 00 & 13 & 24 & 14 & 24 & 226.43 \\
$13: 00$ & 23 & 24 & 23 & 20 & 226.43 \\
$18: 00$ & 21 & 22 & 21 & 19 & \\
Mean \pm S. E. M & $19.00 \pm 3.1$ & $23.33 \pm 0.7$ & $19.33 \pm 2.7$ & $21.00 \pm 0.51$ & \\
\hline
\end{tabular}

Table-2. Post-Transportation Meteorological Data for the Study Period

\begin{tabular}{lccccc}
\hline Hour & \multicolumn{2}{c}{ Ambient Temperature $\left({ }^{\circ} \mathbf{C}\right)$} & & Relative Humidity (\%) & Wind speed (km/ day) \\
\cline { 2 - 4 } & Minimum & Maximum & Dry-bulb & & \\
\hline 06: 00 & 15 & 25 & 14 & 26 & 259.51 \\
13: 00 & 24 & 26 & 24 & 20 & 259.51 \\
18: 00 & 23 & 21 & 20 & 20 & \\
Mean \pm S. E. M & $20.67 \pm 2.85$ & $24.00 \pm 1.53$ & $19.33 \pm 2.91$ & $21.00 \pm 0.67$ & \\
\hline
\end{tabular}

were similar to those obtained during the pre-transportation period $(\mathrm{P}>0.05)$. During the transpor-tation the DBT value inside the vehicle before loading was $12^{\circ} \mathrm{C}$, while that value obtained imme-diately after loading was $18^{\circ} \mathrm{C}$. Thereafter, the DBT rose gradually from $24^{\circ}$ $\mathrm{C}$ in the first hour of the journey, and attained a peak value of $29^{\circ} \mathrm{C}$ in the second hour of the journey. The lowest value of $21^{\circ} \mathrm{C}$ was recorded in the eighth hour of the journey (Table-3). The mean DBT inside the vehicle during the journey was $28.33 \pm 0.79^{\circ} \mathrm{C}$, whereas the mean RH ranged between $34-75 \%$ with a mean of $51.00 \pm 1.5 \%$. Thus, the range was $51 \%$ during the journey. There was a positive correlation ( $\mathrm{r}$ $=0.992, \mathrm{P}<0.01$ ) between the hour of the journey and $\mathrm{RH}$ in experimental and control pigs.

The results of the behavioural activities of experimental pigs and control pigs are shown in Figure 1. The value obtained for behavioural activities of defaecating $(75.00 \pm 12.5 \%)$, urinating $(37.5 \pm 12.5$ $\%)$ and huddling together were higher $(\mathrm{P}<0.05)$ in the control pigs than the corresponding values recorded in the experimental pigs (with values of $58.8 \pm 12.3$, $25.00 \% \pm 11.3,0.00 \% \pm 0.0 \%$, respectively). However, there was no significant $(\mathrm{P}>0.05)$ difference in the percentage values of the number of pigs found exhibiting other activities studied in the experimental and control pigs pre-transportation. The recorded values of behavioural activities of standing, sniffing, mounting, fight and attempt to escape were significantly $(\mathrm{P}<0.05)$ higher in experimental than control pigs, while behavioural activities of lying down (75.0 $\pm 13.0 \%$ ), defaecating $(12.5 \pm 8.5 \%)$ and urinating with a value of $(12.5 \pm 8.5 \%)$ were higher in the control $(\mathrm{P}<0.05)$ than experimental pigs.

\section{Discussion}

The results obtained in the present study showed that the pigs were subjected to a cold and dust-laden wind with high AT, characteristics of harmattan season in the Northern Guinea Savannah zone of Nigeria. This observation agreed with that made by Ayo et al. (1998). Meteorological results obtained during the present study agreed with the previous findings that the harmattan season is thermally stressful to pigs (Adenkola et al., 2009).

The meteorological results obtained demonstrated that transportation of pigs during the thermally stressful harmattan (Adenkola et al., 2009) may adversely affect the pigs; and, consequently, impair the homeostatic mechanisms of the animals. This is

Table-3. Mean Ambient Temperature and Relative Humidity inside the Vehicle during the Long-Term Road Transportation

\begin{tabular}{lcc}
\hline Hour of J ourney & Dry-B ulb $\left({ }^{\mathbf{}} \mathbf{C}\right)$ & Relative Humidity (\%) \\
\hline 30 min & 24 & 75 \\
2 & 29 & 63 \\
4 & 27 & 63 \\
6 & 28 & 63 \\
8 & 21 & 34 \\
Overall Mean \pm SEM & $28.33 \pm 0.79$ & $51.00 \pm 1.50$ \\
\hline Try
\end{tabular}


similar to the findings of Vecerek et al. (2006) that the AT during transport influences the level of well-being in pigs. Such responses have been established to have negative effects on both the health status and productivity of animals (West, 2003). Environmental stress factors have been shown to cause oxidative stress and impair the antioxidant, AA in vivo (Sahin et $a l ., 2001)$. Thus, AA supplementation in the present study attenuated the negative responses of pigs to transportation stress.

The fact that all the pigs, both experimental and control, were standing before transportation indicated that the pigs were mentally alert, an indication of sensiromotor reflex and neuromuscular coordination. This is in agreement with the standard guidelines governing the welfare of pigs during road transportation (Lambooij, 2000; Grandin, 2001) that physically fit pigs should be transported. Pig in the two groups, experimental and control, defaecated and urinated pretransportation. This finding indicated that road transportation induced fear as observed by Frazer and Broom (1990), but the percentage of pigs exhibiting these behavioural activities were higher in the control than experimental pigs post-transportation, thus suggesting that AA has ameliorating effect on brain function as observed by Balz (2003).

The percentage number of pigs that huddled together was more in the control than experimental pigs. This finding could be, due to the fact that stressful harmattan season induced generation of free radicals as observed by Adenkola and Ayo (2009) and that this free radical inhibits the hypothalamic thermostat, rendering it incapable of controlling the body temperature in the control pigs. However, in experimental pigs, AA was able to scavenge these free radicals produced thereby ameliorate the effect of free radical and prevents oxidative stress in experimental pigs. The results of the present study indicated that the number of animals standing increased in pigs treated with AA, whereas in control pigs the number of pigs lying down progressively increased post-transportation.

This finding was in agreement with that of Knowles et al. (1999), who observed that the number of animals standing up progressively declined as the duration of the journey increased; whereas a marked increase in the number of animals lying down occurred post-transportation. In experimental pigs, AA may have prevented the muscular damage often caused by free radical production, leading to muscle glycogen depletion and possibly fatigue and lethargy as indicated by the higher percentage of control pigs lying down. AA is essential for the synthesis of muscle carnitine required for transport and transfer of fatty acids into mitochondria where it can be used for energy production. Adenkola and Anugwa (2007) demonstrated that there is better feed utilization in AA supplemented animal. The mechanism involved in AA controlling defaecation and urination under stress was not investigated.

The result of the present study showed that AA increased the number of animals involved in sniffing and mounting as the values were greater in experimental pigs compared to the control pigs. This showed that AA apparently increased sexual activity in pigs even after transportation. This finding was in agreement with the result of Gubergrits and Lvenevsky (1998) which showed that AA enhanced libido. Furthermore, the present study showed that AA increased aggressiveness in AA-treated pigs as evidenced by increased percentage of pigs involved in fighting post-transportation.

The fact that the percentage of pigs attempting to escape was higher in the experimental pigs compared to control pigs post-transportation supported the findings of Chervyakov et al. (1977), Kondratyev (1988) and Balz (2003) that AA activates the adrenergic system. AA acts as a co-factor for the enzyme dopamine$\beta$-hydroxylase, which catalyzes the conversion of neurotransmitter dopamine to adrenaline.

In conclusion, long-term road transportation of pigs during the harmattan season induces behavioural stress and depression, and AA administration prior to the transportation alleviates the risk of these adverse behavioural stress responses. Therefore AA administration is recommended before road transportation in pigs.

\section{References}

1. Adenkola AY, Anugwa FOI (2007). Effects of dietary supplement of ascorbic acid on performance of piglets in Makurdi, Benue State of Nigeria. Trop. Vet. 25(1): 15-17.

2. Adenkola AY, Ayo JO (2009). Effect of road transportation on erythrocyte osmotic fragility of pigs administered ascorbic acid during the harmattan season in Zaria Nigeria. $J$. Cell Anim. Biol. 3(1): 4-8.

3. Adenkola AY, Ayo JO, Sackey AKB. (2009). Ascorbic acidinduced modulation of rectal temperature in pigs during the harmattan season. J. Thermal Biol. 34 (13): 152-154 .

4. Adenkola AY, Ayo JO, Sackey AKB, Adelaiye AB (2010). Erythrocyte osmotic fragility of pigs administered antioxidant and transported by road for short-term duration during the harmattan season. Afri. J. Biotechnol. 9(2): $226-$ 233.

5. Altan O, Pabuccuaoglu A, Konyalioglu S, Bayracktar H (2002). Effect of heat stress on oxidative stress, lipid peroxidation and some stress parameters in broilers. Brit. Poultry Sci. 44 (4): 54 - 55. 
6. Ayo JO, Oladele, SB, Fayomi A, Jumbo SD, Hambolu JO (1998). Body temperature, respiration and heart rate in the Red Sokoto goat during the harmattan season. Bull. Anim. Produc. Afric. 46: 161-166.

7. Ayo JO, Oladele SB, Fayomi A (2002). Behavioural reactions of cattle to stress situations: A review. J. Agric. Technol. 8: 15-20.

8. Ayo JO, Minka NS, Mamman M (2006). Excitability scores of goats administered ascorbic acid and transported during hot-dry conditions. J. Vet. Sci. 7: 27-131.

9. Balz F (2003). Vitamin C intake. Nutri. Disease, 14: 1 - 18.

10. Bauer ME, Munir MA, Saeed MA, Raz A, Reza FK (2001). Restraint stress is associated with changes in glucocorticoid immunoregulation. Physiol. Behav. 73: 525-532.

11. Broom DM (2003). Causes of poor welfare in large animal during transport. Vet. Res. Comm. 27 (Suppl. 1): 515-518.

12. Brown SN, Knowles TG, Eddwards JE, Warris PD (1999). Behaviour and physiological responses of pigs to being transported for up to 24 hours followed by six hours recovery in lairage. Vet. Rec. 145: 421-426.

13. Buckham Sporer KR, Xiao L, Tempelman RJ, Burton JL, Early B, Crowe MA (2008). Transportation stress alters the circulating steroids environment and neutrophil gene expression in beef bulls. Vet. Imm. Immunopathol., 118: 19-29.

14. Cheryvyakov DK, Yevdokimov PD, Vishker AS (1977). Drugs in Vet. Med., Moscow: Kolos Publishing House, pp 496 (in Russian).

15. Earley B, Fisher AD, O'Riodan EG (2006). Effects of pretransport fasting on the physiological responses of young cattle to 8-hour road transport. Iranian J. Agric. Food Res. 45:51-60.

16. Fazio E, Ferlazzo A (2003). A. Evaluation of stress during handling and transport. Vet. Res. Comm. 27 (Suppl. 1): 519524.

17. Ferlazzo A (2003). Large animal transportation procedures in Europe: Present and future. Vet. Res. Comm. 1:513-514.

18. Frazer AF, Broom DM (1990). Farm Animal Behaviour and Welfare. $3^{\text {rd }}$ edn. CAB International, Wallingford, U.K.

19. Gavinelli AS, Simorin D (2003). The transport of animals in the European Union: The legislation, its enforcement and future evolution. Vet. Res. Comm. $27: 529-534$.

20. Grandin T (2001). Perspectives on transportation issues; the importance of having physically fit cattle and pigs. J. Anim. Sci. 79: 201-207.

21. Gubergrits AY, Linevsky YV (1989). Therapeutic Nutrition Kiev: Vyscha Shkola Publishing House, pp 398 (in Russian).

22. Hartung J (2003). Effects of transport on health of farm animals. Vet. Res. Comm. 27:525-527.

23. Hick TA, Mcglonei JJ, Whisnant CS, Kattesh RL. (1998). Behavioural, endocrine, immune and performance measures for pigs exposed to acute stress. J. Anim. Sci. 76:474-483.

24. Igono MO, Aliu YO (1982). Environmental profile and milk production in Friesian-Zebu crosses in Nigeria Guinea Savanna. Int. J. Biometeorol. 26: 115-120.

25. Igono MO, Molokwu ECI, Aliu YO (1982). Body temperature responses of savanna brown goat to the harmattan and hot-dry season. Int. J. Biometeorol. 26: 225 230.

26. Knowles TG, Brown SN, Edwards JE, Warris PD. (1999). Effect on cattle of transportation by road for up to 31-hours. Vet. Rec. 145: 575- 582 .

27. Kondratyev VC (1988). Analysis of blood system. In: Smirnov. (ed.). Clinical Examination of Internal and Noninfectious Diseases of Livestock. Agropromizdat, Moscow, pp 160-175 (in Russian).

28. Lambooij E (2000). Transport of pigs. In: Grandin, T (ed.). Livestock Handling and Transport. New York; CABI Publishing, pp. 275-296.

29. Naidu KA (2003). Vitamin C in human health and disease is still a mystery ? An overview. Nutr. J. 2: 1-10.

30. Pal R, Gulati K, Chakraborti A, Banerjee B (2008). Ray, A. Role of free radicals in stress-induced neurobehavioural changes in rats. Indian J. Experim. Biol. 44(10): 816-820.

31. Ray A, Gulati K, Vijavan VK. (2007). Free radicals and theophylline neurotoxicity: An experimental study. Cell Mol. Biol. 53(5): 42-52.

32. Rice ME (2000). Ascorbate regulation and its neuroprotective role in the brain. Trends in Neurosci. 23: 209-216.

33. Sahin K, Sahin N, Onderci M, Yaraliogu S, Kucuk O (2001). Protective role of supplemental vitamin E on lipid peroxidation, vitamins E, A and some mineral concentrations of broilers reared under heat stress. Vet. Med. (Czechslosvakia), 46: 140-144.

34. Santiago-Mejia J, Fuentes-Vargas, M, Rios C, Vidrio $\mathrm{H}$, Rodriquez R. (2004). Effect of ascorbic acid, dihydrolipoic acid, t-butylhydroquinone, and phenylbutylnitrone on mortality and neurological impairement induced by sequential common carotid artery sectioning in mice. Drug Dev. Res. 63: 212- 218.

35. Saunders VM, Straub RH. (2002). Norepinephrine, the $\beta$ adrenergic receptor and immunity. Brain Behav. and Imm. 16: 290-332.

36. Vecerek V, Malena M, Malena Jr. M, Vosslarova E, Chloupek $\mathrm{P}$ (2006). The impact of transport distance and season on losses of fattened pigs during trasnsport to the slaughter house in the Czech republic in the period from 1987 to 2004. Vet. Med. (Czechslosvakia), 51(1):21-28.

37. West JW (2003). Effects of heat stress on production in dairy cattle. Amer. Dairy Sci. Assoc. 86: 2131 - 2144. 